\title{
Mineralogical and Geotechnical Characterization of the Clay Layers within the Basal Shear Zone of the 1963 Vajont Landslide
}

\author{
Alberto Bolla ${ }^{1, *(1)}$, Paolo Paronuzzi ${ }^{1}$, Daniela Pinto ${ }^{2}\left(\mathbb{D}\right.$, Davide Lenaz $^{3}{ }^{(1)}$ and \\ Marco Del Fabbro ${ }^{1}$ \\ 1 Polytechnic Department of Engineering and Architecture, University of Udine, 33100 Udine, Italy; \\ paolo.paronuzzi@uniud.it (P.P.); marco.delfabbro@uniud.it (M.D.F.) \\ 2 Department of Earth and Geoenvironmental Sciences, Aldo Moro University of Bari, 70125 Bari, Italy; \\ daniela.pinto@uniba.it \\ 3 Department of Mathematics and Geosciences, University of Trieste, 34128 Trieste, Italy; lenaz@units.it \\ * Correspondence: alberto.bolla@uniud.it; Tel.: +39-0432-558738
}

Received: 17 August 2020; Accepted: 3 September 2020; Published: 6 September 2020

\begin{abstract}
The 1963 Vajont landslide is a reference example of large rockslides involving clay interbeds emplaced in sedimentary rock masses in correspondence with the basal rupture zone (thinly stratified cherty limestone of the Fonzaso Formation dated to Middle-Upper Jurassic). The basal shear zone of the 1963 Vajont landslide was made up of a chaotic assemblage of displaced rock masses, limestone angular gravel, and spread clay lenses. The mineralogical investigations showed that the clays are characterized by complex assemblages of illite/smectite mixed layers (36-96\%) admixed with variable amounts of calcite $(4-64 \%)$ and quartz $(0-6 \%)$. The clay layers show highly variable plasticity properties and shear strength characteristics. The samples with a large prevalence of clay mineral content $(\mathrm{CM})(\mathrm{CM}>79 \%)$ are characterized by low values of the residual friction angle $\left(6.7-14.9^{\circ}\right)$, whereas clay materials characterized by a higher content of granular minerals (calcite and quartz) clearly show greater friction angle values $\left(19.5-26.7^{\circ}\right)$. The high permeability of the limestone angular gravel, which caused a rapid reservoir-induced inflow (1960-1963), together with the low friction angle of the clay layers were responsible for the overall shear strength reduction in correspondence with the basal rupture zone, thus favoring the huge sliding on 9 October 1963.
\end{abstract}

Keywords: Vajont landslide; large rockslide; shear zone; Fonzaso Formation; clay; illite/smectite mixed layer; shear strength; friction angle

\section{Introduction}

Many large rockslides and large-scale slow-moving rock slopes, in both massive and closely stratified rock masses, are characterized by the occurrence of a deep-seated basal rupture zone where deformation and damage caused by shear stresses are concentrated. The thickness and extent of a basal shear zone are strongly influenced by a number of geological and mechanical factors, including size and geometry of the unstable rock mass, confining pressure, attitude of stratification, schistosity or foliation, bed thickness, massive or multilayer structure, occurrence of clay layers or soft joint infill, rock mass anisotropy, and competence contrast [1]. The variation in the stability condition of an unstable rock slope as well as its pre-failure and post-failure mechanical behaviors are mainly governed by the mechanical properties of the materials involved in the formation of the basal shear zone. In some circumstances, shear zones at the base of large rockslides or slow-moving rock slopes include fine-grained or clay materials [2-7]. These materials can have a different origin or formation process. In most cases, clay materials within basal rupture zones have a mechanical origin and occur as a 
result of strong rock comminution and pulverization caused by shear stresses [7-12] or are caused by weathering and alteration of the rock [4,13-17], even if a combination of both rock disruption and weathering is also possible. In addition to the aforementioned processes, in sedimentary rock masses, clay materials can occur as interbeds within the lithostratigraphic sequence involved in the basal rupture $[6,18]$. Clay interbeds included in sedimentary rock sequences can also have a volcanic origin $[19,20]$.

Clay materials occurring within basal shear zones were identified thanks to detailed field surveys of failure scars of some rockslides $[3,10,14,20]$ or by means of drilling or exploration adits performed on large unstable rock slopes $[7,9,11,12,15]$. Mineralogical investigations on clay materials collected from basal shear zones revealed the occurrence of clay minerals that, in most cases, derived from the parent rock involved in the basal disruption $[7,9-12,17]$. In these cases, typical clay minerals found in the soil mixtures are illite and chlorite deriving from gneissic rocks [7,17], greenstones [12], sandstones, and mudstones [10]. Smectite was identified in clay materials resulting from crushing of tuff [2] and shale [11,12], or can derive from physical and chemical alteration under saturated conditions of the primary rocks [4,14-17], even as a result of circulation of sulfuric acid [13]. Smectite is also commonly included in clay interbeds of volcanic origin $[19,20]$. Laboratory investigations on the shear strength of clay materials involved in basal rupture zones demonstrate that lower values of the friction angle $\left(\varphi=7-12^{\circ}\right)$ are commonly related to the presence of smectite $[16,19,20]$, whereas higher values of the friction angle $\left(\varphi=18-35^{\circ}\right)$ were found for fine-grained materials that include illite, chlorite, and other non-swelling clay minerals $[5,7,9]$.

The Vajont landslide that occurred on 9 October 1963 is a reference example of a large slope failure characterized by the presence of clay interbeds included in the sedimentary rock mass that was involved in the basal rupture (thinly stratified cherty and marly limestone of the Fonzaso Formation dated to Middle-Upper Jurassic). The existence of clay layers at the base of the Vajont landslide is universally recognized and is considered a determining factor in the occurrence of the slope failure [21-24]. As a result, most of the geotechnical models of the 1963 Vajont landslide simply consider a single, discrete failure surface at the base of the slide whose shear resistance is assumed to be related to the shear strength of the clay layers $[21,25,26]$. Previous laboratory investigations on the clay materials involved in the Vajont landslide were aimed at determining their mineralogical composition and shear strength properties [21,27-29]. Diffractometric analyses pointed out the presence of a large amount of clay minerals (50-80\%), including montmorillonite [21,27] or illite/smectite mixed layers [29]. One of the most interesting, and perhaps surprising, characteristics of the Vajont clays is the low value of their friction angle $\left(\varphi=5-16^{\circ}\right.$, prevailingly), which contributed to the decrease in the overall shear resistance in correspondence with the basal rupture zone and, consequently, favored the huge sliding. However, the actual influence of the specific mineralogical composition on the shear strength characteristics of the Vajont clays has not been comprehensively analyzed or fully understood. To address this issue, we present in this work the results of a geochemical, mineralogical, and geotechnical investigation performed on several clay samples collected from the Vajont landslide and from a comparable in situ Jurassic-Cretaceous sequence occurring in the surrounding area.

\section{The 1963 Vajont Landslide}

On 9 October 1963, in the Vajont valley (NE Italy, Municipality of Erto and Casso), an enormous mass of rocks and debris (270-300 million $\mathrm{m}^{3}$ ) detached from the northern slope of Mt. Toc and slid into the adjacent reservoir created by a concrete double-curvature arch dam (Figure 1). The large mass movement triggered a huge wave that inundated the Vajont valley and, after overtopping the dam, flooded into the underlying Piave valley, destroying the town of Longarone and the nearby villages and killing about 2000 people. This event represents a reference case history for scientists and researchers dealing with large landslides and/or reservoir-induced slope failures and is considered a milestone in the general development of rock and soil mechanics [30,31]. This famous landslide has 
attracted a lot of scientific interest over time, owing to its complexity and the need to understand the underlying mechanisms that caused the slope failure $[21,23,26,32-40]$.

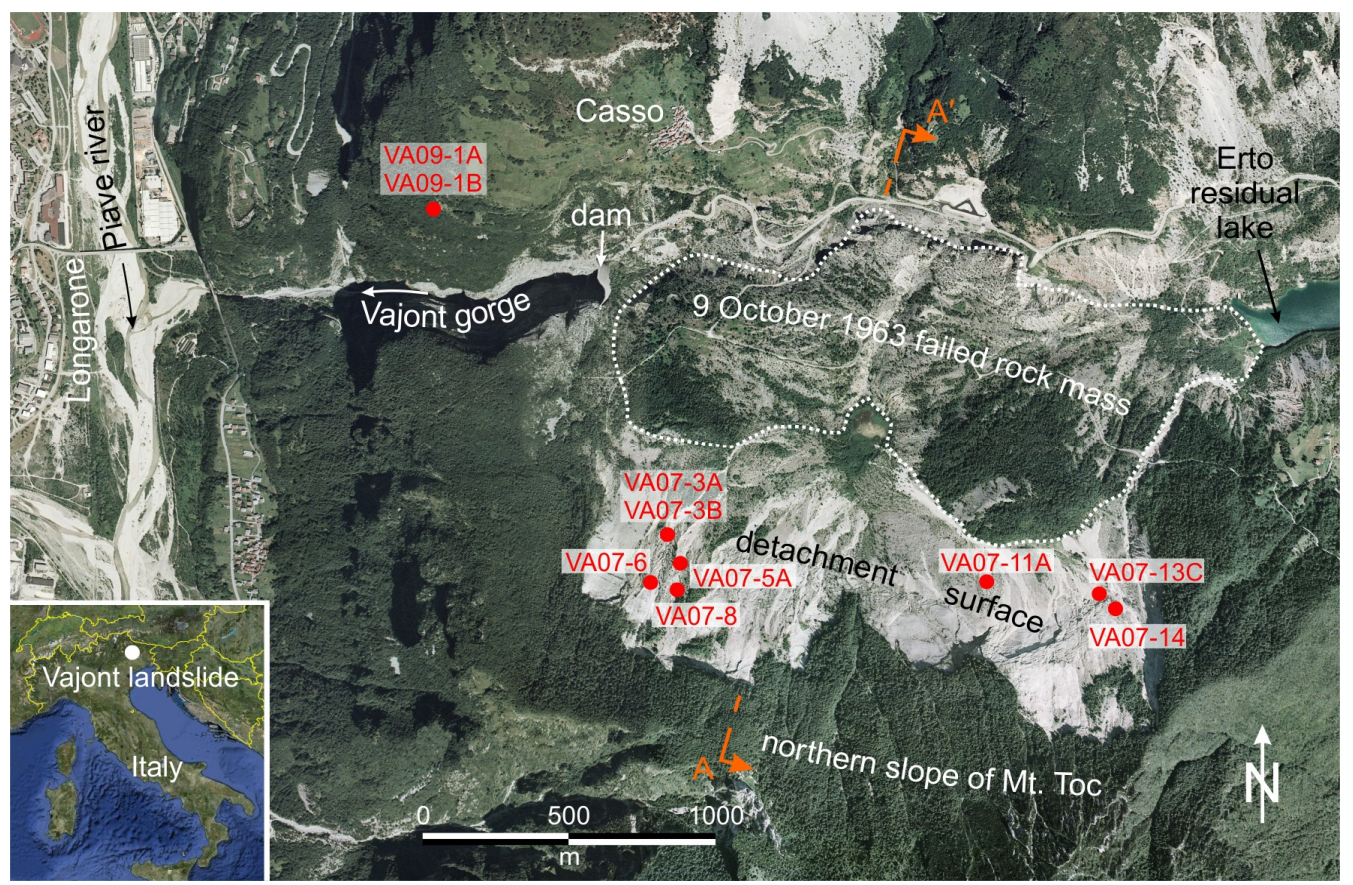

Figure 1. Orthophoto of the final stretch of the Vajont valley showing the detachment surface and the failed rock mass of the 1963 Vajont landslide. The location of the clay samples analyzed in the present study and the trace of the geological cross-section are also shown.

The 1963 Vajont landslide mobilized a rock mass made up of a complex cherty and marly limestone sequence dating from Middle-Upper Jurassic to Upper Cretaceous, including the following geological Formations (Fm.), from the bottom to the top (Figure 2a):

- $\quad$ Fonzaso (FOZ);

- Ammonitico Rosso Veronese Superiore $\left(\mathrm{ARV}_{3}\right)$;

- Maiolica (MAI); and

- $\quad$ Scaglia Variegata Alpina (lower member $\mathrm{VAA}_{1}$ and upper member $\mathrm{VAA}_{2}$ ).

The basal failure surface of the slide formed within the Fonzaso Fm., about 10-15 m above the lithostratigraphic contact with the underlying Calcare del Vajont (OOV) Fm. (Figure 2a). The Fonzaso Fm. is characterized by a thinly stratified sequence (average thickness: $5-10 \mathrm{~cm}$ ) of cherty and marly limestone with frequent clay interbeds of variable thickness, from $0.2 \mathrm{~cm}$ to $6 \mathrm{~cm}$, in most cases (Figure 2b). Some occasional thicker clay lenses occur, even reaching $20 \mathrm{~cm}$ of thickness. Clay interbeds do not occur diffusely within the Fonzaso Fm., but multiple and overlying clay lenses concentrate in some specific rock strata sequences of low thickness (1-2 m thick).

The 1963 landslide was the reactivation of a prehistoric rockslide and was characterized by an en-block motion of a rigid overlying rock mass (100-130 m thick, on average) that moved downslope sliding onto a very thick shear zone (40-50 m thick, on average) made up of a chaotic assemblage of displaced rock masses, limestone angular gravel, and spread clay lenses [1,22]. The geometry and structure of the northern slope of Mt. Toc before 9 October 1963 (Figure 3a) were the result of the landslide accumulation related to the ancient, multistage, and retrogressive slope failure that probably occurred in the late Pleistocene-early Holocene period [1,22,23]. The debris materials forming the basal shear zone were mainly created by the disruption of the primary rock mass at the base of the slide during the ancient propagation. The prehistoric dynamic stage caused the shearing-off of rock masses, the strong fracturing of limestone layers, and the heavily comminution of the rock (Figure 3b,c). 
The en-block motion that affected the large assembled block mobilized during the 1963 reactivation was caused by the interposed ductile shear zone that acted as a debris cushion.

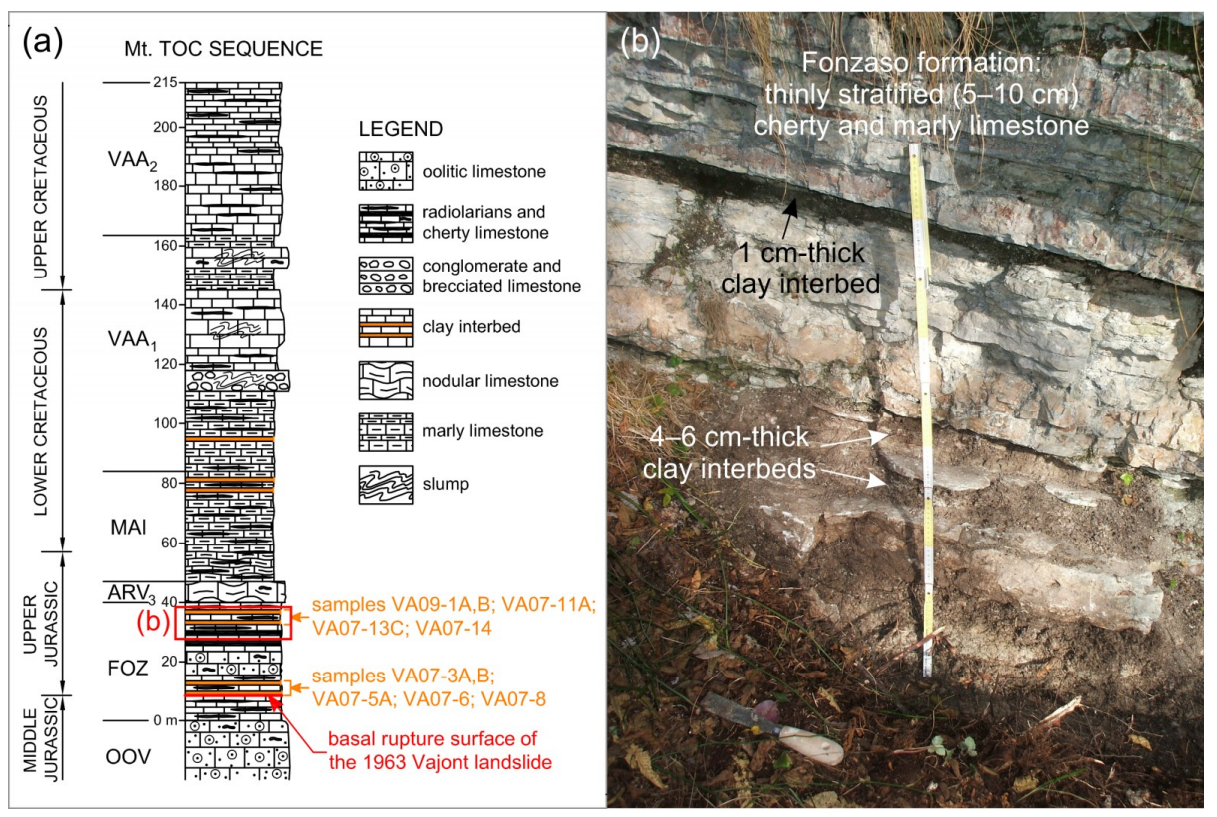

Figure 2. (a) Lithostratigraphic column involved in the 1963 Vajont landslide. The location and code of the clay samples are shown. (b) In situ cherty and marly limestone sequence (top of the Fonzaso Formation) outcropping near the village of Casso (for the outcrop location, see Figure 1).
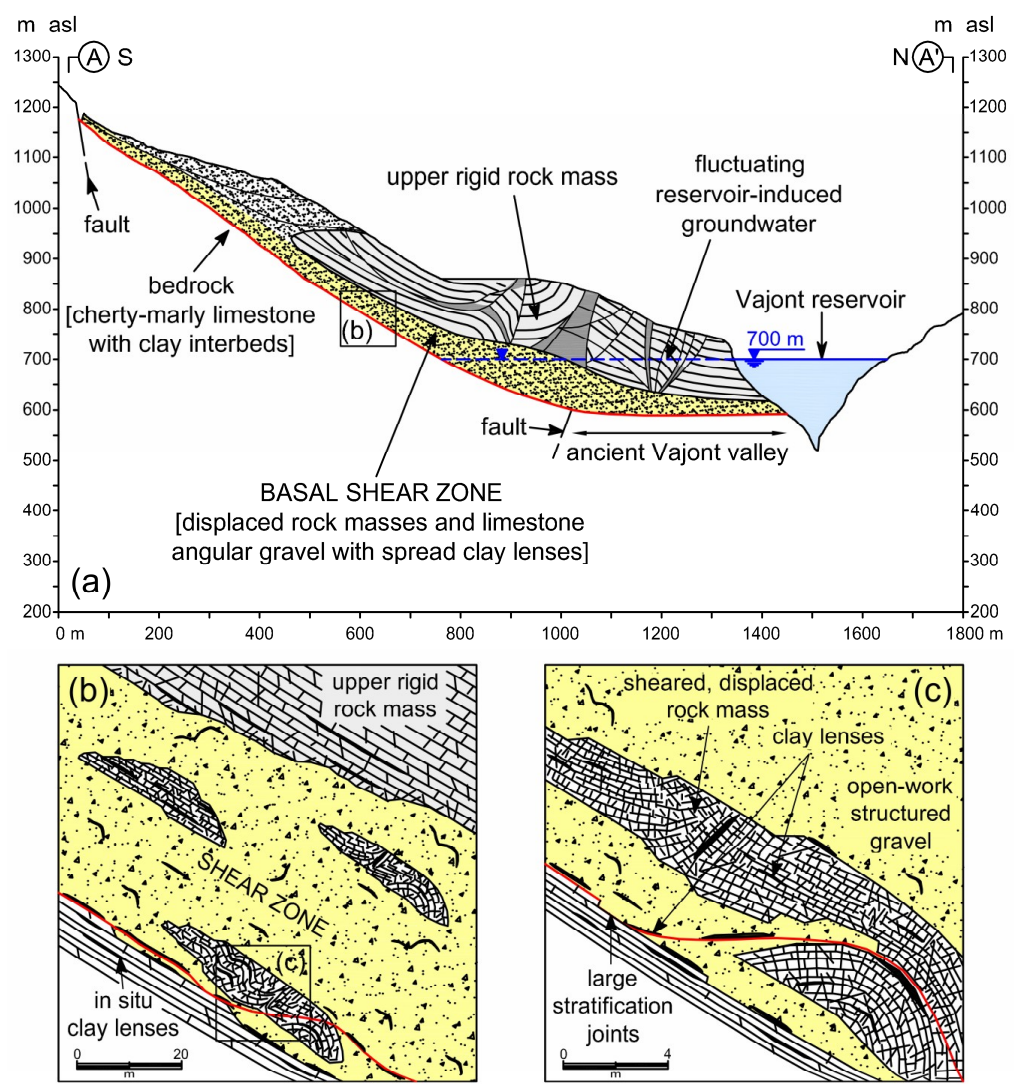

Figure 3. (a) Geological cross-section of the Vajont slide before 9 October 1963 displaying the thick shear zone interposed between the upper rock mass and the underlying bedrock. (b,c) The failure surface involved different materials within the basal shear zone (modified figure from [24]). 
The major field evidence for the presence of loose materials at the base of the Vajont landslide lies in the identification of a number of remnants of the primary shear zone still exposed on the large failure scar created by the 1963 slide (Figure 4a). The maximum thickness of the remnants of the shear zone can be estimated at about 10-12 m, and the sheared materials mainly belong to FOZ. The shear zone material is made up of limestone angular gravel that is strictly associated with large blocks of strongly fractured and folded rock masses still preserving the stratification (Figure $4 \mathrm{~b}, \mathrm{c}$ ).
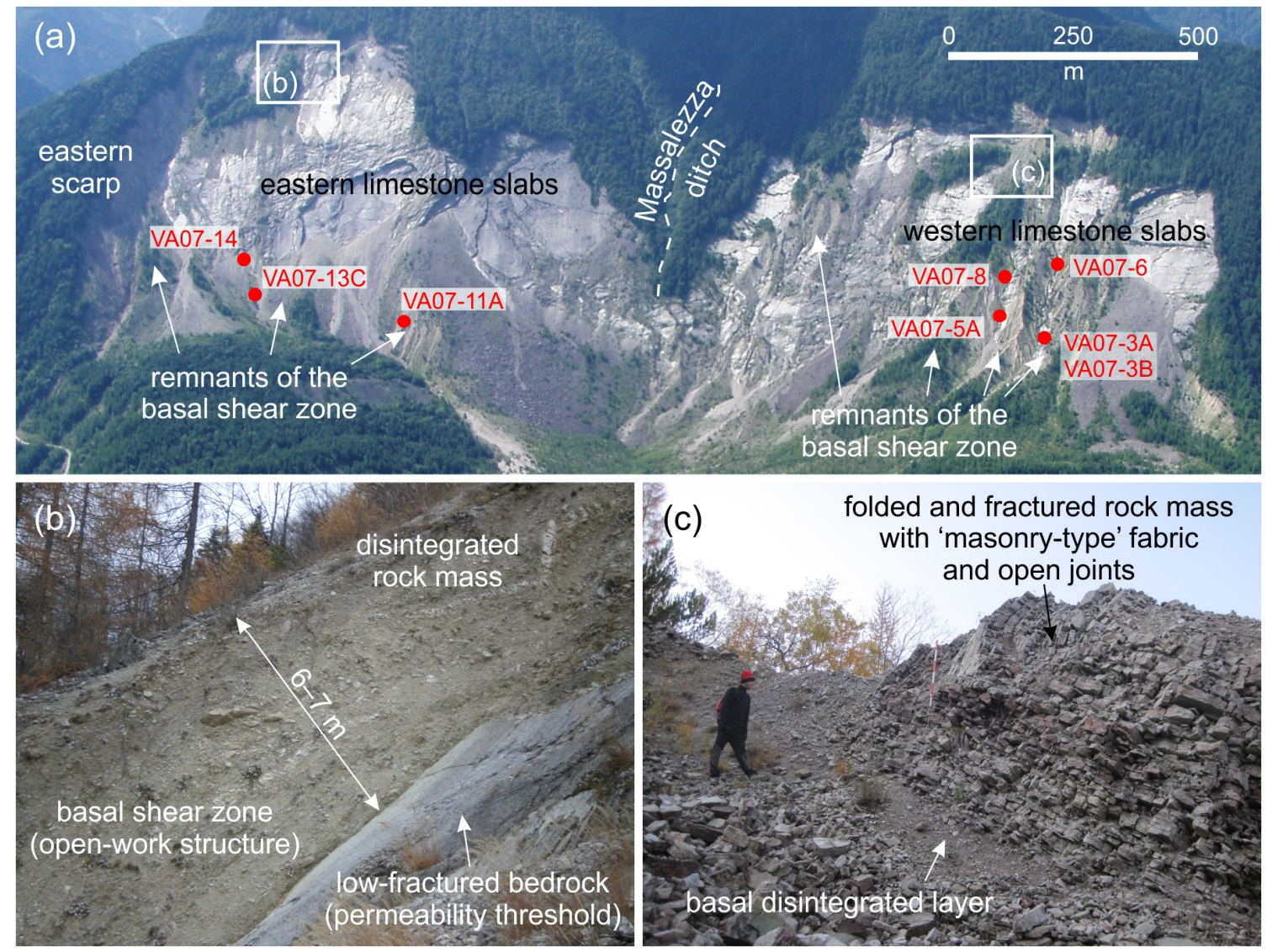

Figure 4. (a) Failure scar of the 1963 Vajont landslide, showing widespread presence of remnants of the basal shear zone. The location and code of some clay samples are also shown. (b) Basal contact between the main rupture surface and the overlying debris of the shear zone. (c) Displaced and stratified rock mass "wrapped" by a layer made up of angular gravel.

The field survey of the failure scar ascertained the presence of a large amount of clay materials in different geological contexts (Figure 5). Clay layers occur in correspondence with the basal failure surface (Figure 5a), within the displaced stratified rock masses (Figure 5b), or are mixed with angular gravel (Figure 5c). Clay materials are made up, as a rule, of interbeds or lenses (thickness: from $0.2-0.5 \mathrm{~cm}$ to $5-6 \mathrm{~cm}$, in most cases) delimited by limestone layers (stratified rock masses) or thicker beds of limestone gravel. Over widespread areas of the detachment surface, the presence of isolated lenses of yellowish, green, and gray clay can be noted (Figure 5). Most clay lenses have low continuity (1-15 m). Sometimes the clay layers appear strongly deformed and create folded lenses (Figure 5d). As ascertained for the in situ lithostratigraphic sequence (Figure 2b), multiple clay lenses are concentrated in some specific rock strata sequences (sheared-off rock masses) or debris strips of low thickness (1-2 m). 



Figure 5. (a) Clay layers (cm thick) sampled from the detachment surface of the 1963 Vajont landslide. On the field, the clays mainly appear as yellow, (b) green, (c) or gray (d) lenses that can also be heavily folded.

\section{Field Sampling and Laboratory Testing}

A field survey was carried out for this work in order to identify, localize, and sample clay materials occurring within the lithostratigraphic sequence that was involved in the 1963 Vajont landslide. The survey was performed on the large failure scar of the slide as well as on the opposite valley side near the village of Casso, where the in situ Jurassic-Cretaceous sequence is better exposed (Figure 1). During the field survey of the detachment surface, eight clay samples were collected from the basal shear zone resting on both the western and eastern limestone slabs (Figures 1 and $4 \mathrm{a}$ ). For comparison purposes, two additional clay samples were collected from the in situ lithostratigraphic sequence that outcrops on the opposite valley side (Figures 1 and $2 b$ ).

The outcrops of clay materials were accurately prepared before the sampling procedure, removing the surface debris and the soil cover and pointing out the main stratigraphical contacts (Figure $2 b$ ). In some outcrops, multiple clay layers occur, thus more samples were acquired from the same location (for instance, VA09-1A, B). The clay samples collected from the field were subsequently analyzed in the laboratory to investigate their geochemical, mineralogical, and geotechnical characteristics.

X-ray fluorescence (XRF) analyses were performed via a WDS sequential Philips PW2400 spectrometer, operating under vacuum conditions and equipped with a $3 \mathrm{~kW}$ Rh X-ray tube, 5 analyzing crystals (lithium fluoride LiF220, LiF200, Germanium Ge, pentaerythritol PE, and thallium(I) hydrogen phthalate TIAP), 2 detectors (flow counter and scintillator), 3 collimators ( $150 \mu \mathrm{m}, 300 \mu \mathrm{m}$, and $700 \mu \mathrm{m})$, and 4 filters ( $\mathrm{Al} 200 \mu \mathrm{m}$, Brass $100 \mu \mathrm{m}, \mathrm{Pb} 1000 \mu \mathrm{m}$, and Brass $300 \mu \mathrm{m}$ ). The analyses were performed on glass bead samples (1:10 ratio with flux $\mathrm{Li}_{2} \mathrm{~B}_{4} \mathrm{O}_{7}$ ), whereas the $\mathrm{FeO}$ content was determined via permanganometry. The $\mathrm{X}$-ray fluorescence analyses were carried out at the Department of Geosciences of the University of Padua (Padua, Italy). 
With the only exception of sample VA07-6, all clay samples were analyzed for mineralogical characterization by X-ray powder diffraction (XRPD) method. The analyses were performed at the Department of Earth and Geoenvironmental Sciences of the University of Bari A. Moro (Bari, Italy) using a PANalytical Empyrean diffractometer equipped with a Real Time Multiple Strip (RTMS) PIXcel ${ }^{3 \mathrm{D}}$ detector and $\mathrm{Cu}-\mathrm{K} \alpha$ radiation. Analytical conditions were as follows: $40 \mathrm{~mA}$ and $40 \mathrm{kV}$; $0.125^{\circ}$ divergence slit, $0.25^{\circ}$ antiscattering slit and soller slit ( $0.02 \mathrm{rad}$ ) on the incident beam; Ni filter, soller slit $(0.02 \mathrm{rad})$ and antiscatter blade $(7.5 \mathrm{~mm})$ on the diffracted beam. Both qualitative and semi-quantitative mineralogical analyses were performed on the selected samples.

Qualitative analyses were carried out on bulk samples and on clay fractions separated by settling according to Stokes' law. Oriented mounts of all the samples (clay fraction $<2 \mu \mathrm{m}$ ) were prepared and XRPD measurements were performed on air-dried, ethylene glycol-saturated, and heated $\left(550{ }^{\circ} \mathrm{C}\right)$ oriented samples in order to identify clay minerals [41]. Bulk XRPD data were collected from carefully ground powders in the angular range of $3-70^{\circ}(2 \theta)$ with a virtual step scan of $0.026^{\circ}$ and a counting time of $360.0 \mathrm{~s} /$ step and using side-loaded sample holders. XRPD data were processed using X'Pert High Score 3.0e software, which includes the ICSD database and a profile fitting tool for accurate peak position and peak area determination.

Semi-quantitative mineralogical determination of clay and non-clay minerals in bulk samples was carried out by measuring peak areas in the diffractograms of random preparations according to the procedure described in [42]. The strongest reflection at $3.03 \AA$ was used for calcite, whereas for the quantification of quartz the line at $4.26 \AA$ was used instead of the strongest one at $3.34 \AA$, in order to avoid superimposition effects with $10 \AA$-minerals and illite/smectite (I/S) mixed layer series. The total clay mineral content (CM) was estimated measuring the $4.5 \AA$ peak area.

Finally, all soil samples collected from the field were prepared and quartered for geotechnical analyses, determining the following: grain-size distribution, Atterberg limits, plasticity and activity indexes, and residual shear strength properties. The geotechnical analyses were performed at the Polytechnic Department of Engineering and Architecture at the University of Udine (Udine, Italy). The sub-samples submitted to the grain size analyses were washed and sieved to separate the coarse-grained part (retained on the American Society for Testing and Materials (ASTM) No. 200 sieve) from the fine fraction. The coarse-grained soils were subsequently oven-dried at about $105^{\circ} \mathrm{C}$ and their grain-size distribution was determined through mechanical sieving with a complete set of ASTM sieves (from 3" to No. 200). The fine fraction was analyzed through sedimentation employing a hydrometer and performing readings up to four days.

The sub-samples submitted to plasticity and residual shear strength analyses were air-dried so as not to alter their mineralogical characteristics and subsequently sieved to obtain the fraction passing the ASTM No. 40 sieve. Plasticity properties of the soil samples were determined according to the standard procedures described in ASTM D4318. The liquid limit was determined using the multipoint method and the Casagrande cup, whereas the plastic limit was assessed following the hand-rolling procedure.

The residual shear tests were carried out on seven selected clay samples using a ring shear machine Bromhead WF 25850 and considering three different confining pressures, namely $200 \mathrm{kPa}, 400 \mathrm{kPa}$, and $600 \mathrm{kPa}$. The tested materials were previously saturated with distilled water to reach a water content equal to the corresponding limit liquid. The tested ring specimens had an outer diameter of $100 \mathrm{~mm}$, an inner diameter of $70 \mathrm{~mm}$, and a thickness of $5 \mathrm{~mm}$. Because of the high initial water content of the remolded samples, multistage consolidations were slowly performed until the desired normal stresses were reached in order to minimize the leak of material and to control the vertical displacements. The drained residual shear strength of the tested materials was assessed employing a very low displacement rate, equal to $0.024 \mathrm{~mm} / \mathrm{min}$, in order to avoid the development of pore water overpressures. The shear stage was prolonged until stable residual strength conditions were reached at large deformations, which usually corresponds with pluri-centimetric displacements. 


\section{Results}

\subsection{Geochemistry and Mineralogy}

The analyzed samples are characterized by high values of loss on ignition (LOI) in the range of 14-33 wt.\% (Table 1). When considering anhydrous chemical analyses (normalized to 100, excluding LOI), the most abundant oxides are $\mathrm{SiO}_{2}$ in the range of 30-60 wt.\% (avg. 52 wt.\%; Std. Dev. 9), $\mathrm{CaO}$ in the range of 5-52 wt.\% (avg. $21 \mathrm{wt} . \%$; Std. Dev. 14), and $\mathrm{Al}_{2} \mathrm{O}_{3}$ in the range of 10-20 wt.\% (avg. 16 wt.\%; Std. Dev. 4). Among the other oxides, $\mathrm{FeO}_{\text {tot }}, \mathrm{K}_{2} \mathrm{O}$, and $\mathrm{MgO}$ comprise between 1 and 6 wt.\% (avg. 2.6-4.7 wt.\%). All the other oxides are below 0.5 wt.\% (Table 1).

Table 1. Anhydrous weight percentage of oxides from X-ray fluorescence (XRF) analysis of clay samples from Vajont and Loss On Ignition (LOI) content.

\begin{tabular}{|c|c|c|c|c|c|c|c|c|c|c|c|c|}
\hline \multirow{2}{*}{ Sample } & \multicolumn{10}{|c|}{ Oxides (wt.\%) } & \multirow[b]{2}{*}{ Total } & \multirow{2}{*}{$\begin{array}{c}\text { LOI } \\
(\%)\end{array}$} \\
\hline & $\mathrm{SiO}_{2}$ & $\mathrm{TiO}_{2}$ & $\mathrm{Al}_{2} \mathrm{O}_{3}$ & $\mathrm{Fe}_{2} \mathrm{O}_{\text {tot }}$ & $\mathrm{MnO}$ & $\mathrm{MgO}$ & $\mathrm{CaO}$ & $\mathrm{Na}_{2} \mathrm{O}$ & $\mathrm{K}_{2} \mathrm{O}$ & $\mathrm{P}_{2} \mathrm{O}_{5}$ & & \\
\hline VA07-3A & 50.70 & 0.18 & 16.76 & 2.68 & 0.04 & 5.47 & 22.07 & 0.08 & 2.24 & 0.03 & 100.25 & 24.81 \\
\hline VA07-3B & 46.83 & 0.11 & 11.52 & 1.88 & 0.05 & 3.60 & 34.11 & 0.10 & 1.17 & 0.04 & 99.41 & 28.24 \\
\hline VA07-5A & 29.98 & 0.15 & 9.94 & 2.34 & 0.13 & 2.61 & 51.74 & 0.01 & 2.30 & 0.17 & 99.37 & 32.70 \\
\hline VA07-6 & 54.50 & 0.53 & 18.19 & 2.84 & 0.02 & 5.12 & 16.16 & 0.03 & 2.53 & 0.05 & 99.97 & 22.76 \\
\hline VA07-8 & 52.22 & 0.14 & 11.00 & 2.00 & 0.06 & 3.49 & 28.47 & 0.07 & 1.79 & 0.08 & 99.32 & 25.09 \\
\hline VA07-11A & 58.41 & 0.50 & 17.98 & 3.64 & 0.02 & 5.58 & 9.03 & 0.08 & 4.57 & 0.05 & 99.86 & 17.12 \\
\hline VA07-13C & 54.91 & 0.27 & 16.59 & 2.49 & 0.03 & 4.59 & 17.79 & 0.05 & 3.11 & 0.05 & 99.88 & 22.02 \\
\hline VA07-14 & 59.61 & 0.53 & 20.02 & 2.57 & 0.01 & 6.00 & 4.84 & 0.04 & 5.77 & 0.05 & 99.44 & 13.70 \\
\hline VA09-1A & 54.76 & 0.48 & 17.53 & 3.33 & 0.06 & 5.08 & 15.22 & 0.04 & 3.19 & 0.10 & 99.79 & 23.25 \\
\hline VA09-1B & 56.75 & 0.16 & 18.48 & 2.47 & 0.03 & 5.36 & 13.70 & 0.05 & 2.60 & 0.03 & 99.63 & 22.09 \\
\hline
\end{tabular}

XRPD analyses showed the occurrence of significant contents of clay minerals (from 36\% to $96 \%$ ) in all the investigated samples (Table 2), in addition to variable amounts of calcite (from $4 \%$ to $64 \%$ ) and minor quartz (up to 6\%). Clay minerals exclusively consist of highly disordered illite/smectite (I/S) interstratifications with complex admixtures of $R 0$ and $R 1$ (Reichweite $(R)$ ) stacking orders (see [41]) and illite content ranging generally from $50 \%$ to $85 \%$ (Table 2). Very small diffraction peaks of K-feldspar, kaolinite, illite, and chlorite were occasionally observed in the diffractograms, but the amount of these minerals was not determined as they are present only as traces (below 1\%).

Table 2. Mineralogical composition of clay samples from Vajont.

\begin{tabular}{|c|c|c|c|c|c|c|}
\hline Sample & $\begin{array}{l}\text { Sampling } \\
\text { Location }\end{array}$ & Reichweite & Illite Percentage & $\begin{array}{c}\text { Clay Minerals } \\
\text { (wt. } \% \text { ) }\end{array}$ & $\begin{array}{l}\text { Calcite } \\
\text { (wt. } \% \text { ) }\end{array}$ & $\begin{array}{l}\text { Quartz } \\
\text { (wt.\%) }\end{array}$ \\
\hline VA07-3A & Failure scar, West & $R 0, R 1$ & $50-60 \%, 60-70 \%$ & 83 & 17 & $<1$ \\
\hline VA07-5A ${ }^{b}$ & Failure scar, West & $R 1, R 0$ & $60-70 \%$ and $80-85 \%, 50 \%$ & 36 & 64 & $<1$ \\
\hline VA07-8 & Failure scar, West & $R 0, R 1$ & $50-60 \%, 70-80 \%$ & 60 & 34 & 6 \\
\hline VA07-11A & Failure scar, East & $R 1, R 0$ & $60-70 \%, 50 \%$ & 90 & 9 & 1 \\
\hline VA07-14 ${ }^{\mathrm{c}}$ & Failure scar, East & $R 1$ & $70-80 \%$ & 96 & 4 & 0 \\
\hline VA09-1A & Casso & $R 0, R 1$ & $50-60 \%, 80-85 \%$ & 79 & 19 & 2 \\
\hline VA09-1B & Casso & $R 0, R 1$ & $50-60 \%, 80-85 \%$ & 89 & 10 & 1 \\
\hline
\end{tabular}

${ }^{\mathrm{a}}$ Kaolinite and illite as traces (not determined); ${ }^{\mathrm{b}}$ Kaolinite as traces (not determined); ${ }^{\mathrm{c}}$ Feldspars as traces (not determined); n.d.: not determined

According to semi-quantitative mineralogical estimations (Table 2), samples can be divided into two groups on the basis of the relative proportions of clay minerals and calcite. The first group (samples VA07-3A, VA07-11A, VA07-13C, VA07-14, VA09-1A, and VA09-1B) is in fact characterized by higher amounts of clay minerals (from 79\% to 96\%; Figure 6a), whereas the second group (samples VA07-3B, VA07-5A, and VA07-8) shows a higher calcite content (from 34\% to 64\%; Figure 6b). 
(a)

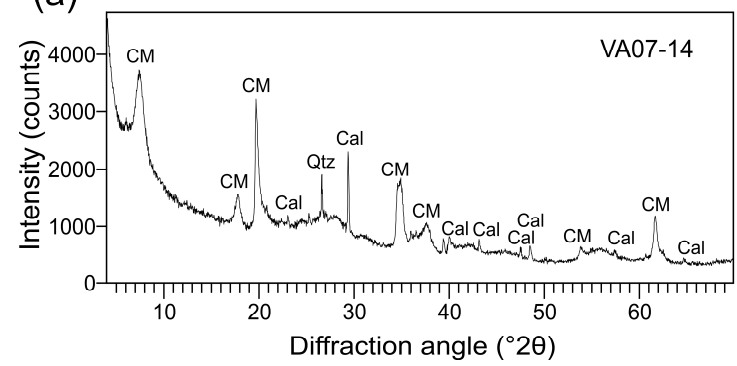

(b)

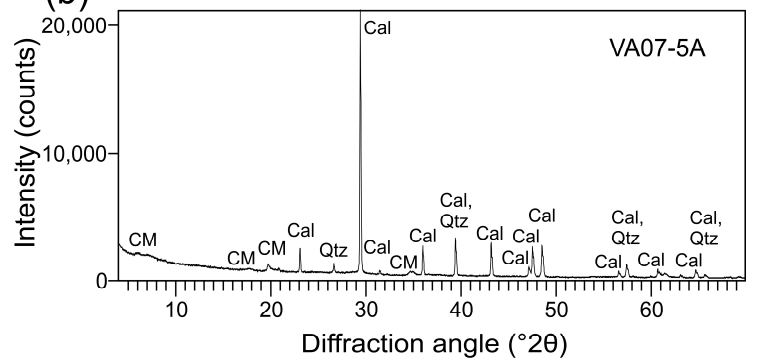

Figure 6. X-ray powder diffraction patterns of two representative samples from Vajont: (a) clay-rich sample VA07-14 and (b) calcite-rich sample VA07-5A.

\subsection{Geotechnical Characterization}

The geotechnical index properties of the clay materials sampled from Vajont are listed in Table 3. According to the grain-size distribution analysis, the soil samples include both silty clays and clayey sandy silts (Figure 7). Interestingly, the samples collected from the eastern detachment plane of the slide (samples VA07-11A, VA07-13C, and VA07-14) have higher values of clay fraction (CF), ranging between $52 \%$ and $63 \%$. The samples coming from the western part of the detachment surface as well as those collected from the in situ lithostratigraphic sequence outcropping on the opposite valley side have a clay fraction included in the range $\mathrm{CF}=18-31 \%$ (Table 3 ). The Atterberg limits of the clayey soils are rather variable (Table 3) - the liquid limit (LL) varies considerably, with values ranging from $38 \%$ to $89 \%$, whereas the plastic limit (PL) varies in the range of $17-43 \%$. As a result, the plasticity index (PI) is highly variable, ranging between $21 \%$ and $59 \%$. The plasticity chart of Figure 8 a reflects the significant variability in the plasticity properties of the Vajont clays. However, most of the samples fall in the field included between the A-line [43] and the U-line [44]. Most of the fine-grained samples from Vajont are classified as normal or active clays (Figure 8b), whereas only one sample (VA07-14) is classified as inactive clay, despite its largest content in clay fraction (Table 3).

Table 3. Geotechnical index properties and residual friction angles of clay samples from Vajont.

\begin{tabular}{|c|c|c|c|c|c|c|c|c|c|c|}
\hline \multirow{2}{*}{ Sample } & \multirow{2}{*}{ Sampling Location } & \multicolumn{4}{|c|}{ Grain-Size Distribution } & \multirow{2}{*}{$\begin{array}{c}\begin{array}{c}\text { Liquid } \\
\text { Limit }\end{array} \\
\text { LL (\%) }\end{array}$} & \multirow{2}{*}{$\begin{array}{c}\begin{array}{c}\text { Plastic } \\
\text { Limit }\end{array} \\
\text { PL }(\%)\end{array}$} & \multirow{2}{*}{$\begin{array}{c}\begin{array}{c}\text { Plasticity } \\
\text { Index }\end{array} \\
\text { PI (\%) }\end{array}$} & \multirow{2}{*}{$\begin{array}{c}\begin{array}{c}\text { Activity } \\
\text { Index }\end{array} \\
\text { AI (-) }\end{array}$} & \multirow{2}{*}{$\begin{array}{c}\begin{array}{c}\text { Residual } \\
\text { Friction Angle }\end{array} \\
\varphi_{\text {res }}\left(^{\circ}\right)\end{array}$} \\
\hline & & G (\%) & $\mathrm{S}(\%)$ & M (\%) & CF (\%) & & & & & \\
\hline VA07-3B & Failure scar, West & 15 & 15 & 43 & 27 & 62 & 37 & 25 & 0.9 & - \\
\hline VA07-5A & Failure scar, West & 15 & 28 & 38 & 18 & 38 & 17 & 21 & 1.2 & $25.1-26.7$ \\
\hline VA07-6 & Failure scar, West & 18 & 19 & 37 & 25 & 67 & 31 & 36 & 1.4 & $8.9-10.8$ \\
\hline VA07-13C & Failure scar, East & 9 & 19 & 20 & 52 & 89 & 30 & 59 & 1.2 & $7.5-9.1$ \\
\hline VA07-14 & Failure scar, East & 3 & 8 & 26 & 63 & 62 & 31 & 31 & 0.5 & - \\
\hline VA09-1A & Casso & 3 & 40 & 26 & 31 & 77 & 39 & 38 & 1.2 & $6.7-9.7$ \\
\hline VA09-1B & Casso & 1 & 35 & 39 & 25 & 71 & 43 & 28 & 1.1 & - \\
\hline
\end{tabular}

Legend: $\mathrm{G}=$ gravel; $\mathrm{S}=$ sand; $\mathrm{M}=$ silt; $\mathrm{CF}=$ clay fraction. 


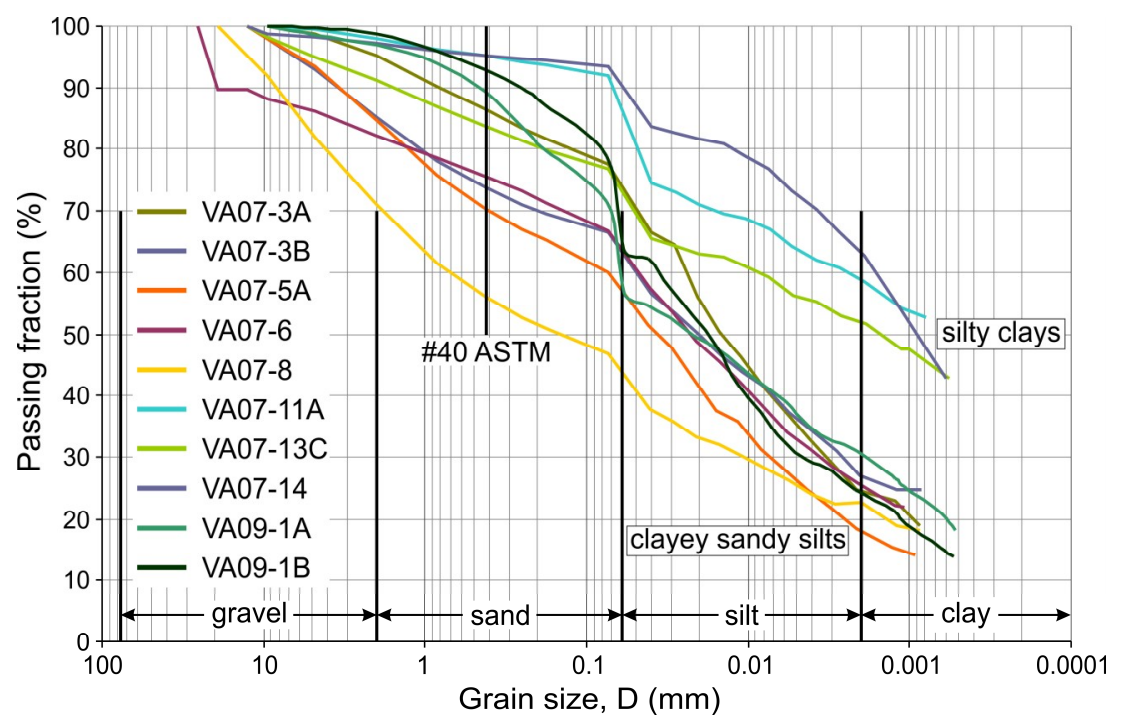

Figure 7. Grain-size distribution curves of soil samples collected from the basal shear zone of the Vajont slide.

The results of the residual shear tests that were performed on seven Vajont clay samples are shown in Figure 9, where the values of the normalized residual shear strength $\left(\tau_{\mathrm{r}} / \sigma^{\prime}\right)$ determined for the three reference values of the effective normal stress $\left(\sigma^{\prime}\right)$ are displayed. The tested samples clearly show highly variable values of the residual shear strength, ranging from $\tau_{\mathrm{r}}=70 \mathrm{kPa}$ to $\tau_{\mathrm{r}}=280 \mathrm{kPa}$ for an effective normal stress of $600 \mathrm{kPa}$. An overall nonlinear decrease of $\tau_{\mathrm{r}} / \sigma^{\prime}$ as $\sigma^{\prime}$ increases is clearly shown. However, the normalized residual shear strength tends to a constant value for higher normal stresses (Figure 9). The shear tests also allowed for the estimation of the residual friction angle values of the tested samples (Table 3). On the basis of the estimated values of $\varphi_{\text {res, }}$ two main groups of clay materials can be identified. The first group of clays (samples VA07-3A, VA07-6, VA07-11A, VA07-13C, and VA09-1A) is characterized by lower values of $\varphi_{\text {res, }}$ varying in the range of $6.7-14.9^{\circ}$, whereas the second group of clays (samples VA07-5A and VA07-8) exhibits higher values of $\varphi_{\text {res, }}$, varying in the range of $19.5-26.7^{\circ}$ (Table 3 ).

(a)

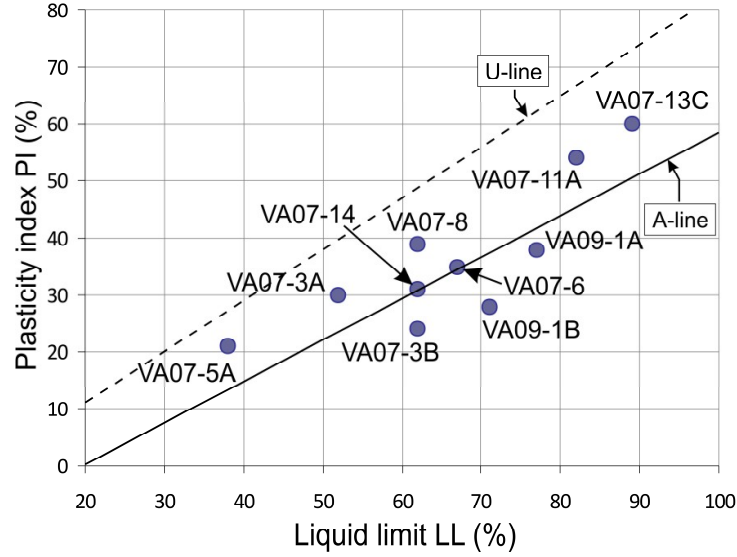

(b)

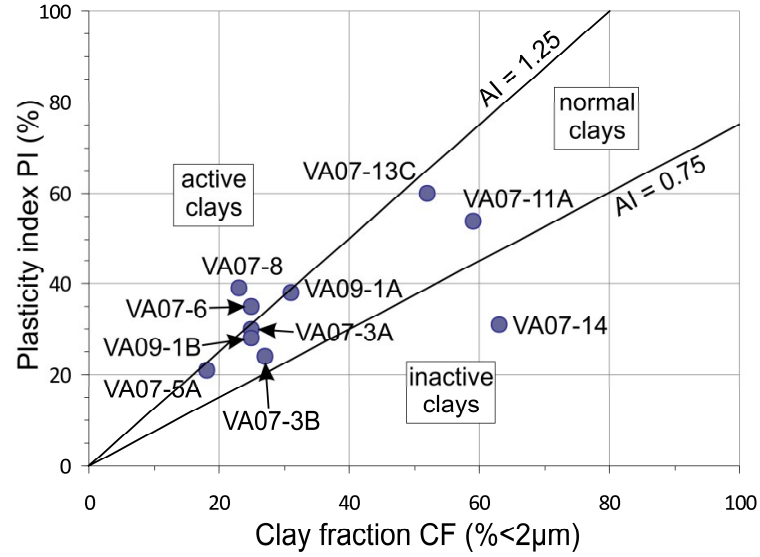

Figure 8. (a) Plasticity chart and (b) activity chart of the clay materials involved in the basal rupture of the 1963 Vajont landslide. 


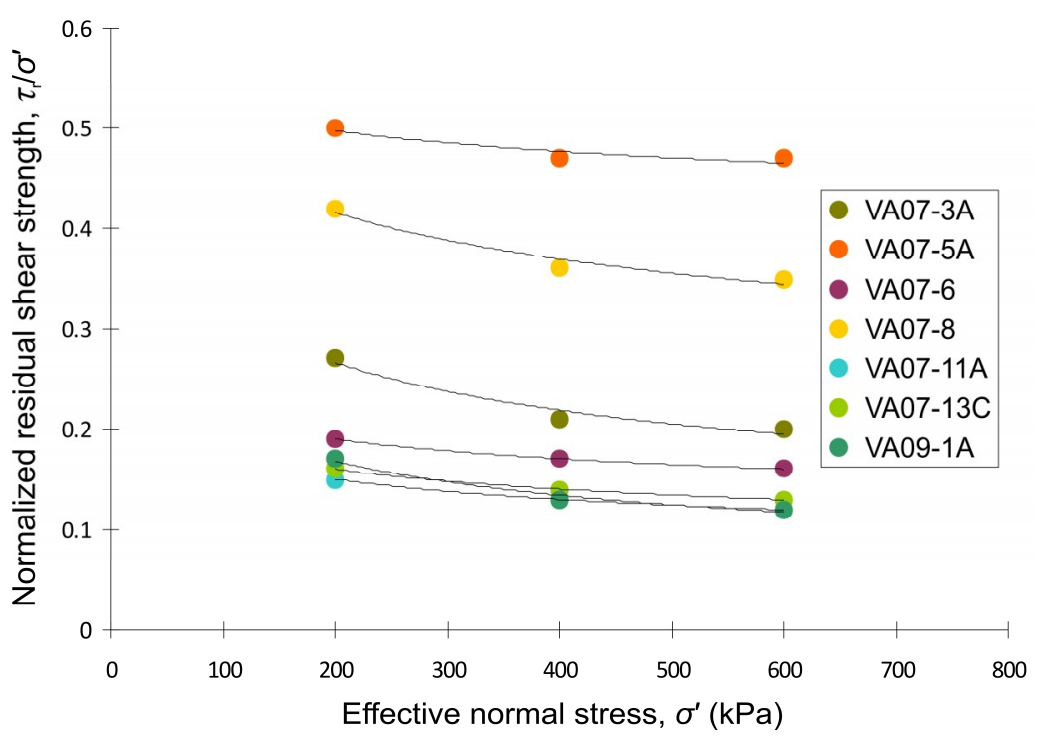

Figure 9. Normalized residual shear strength as a function of the effective normal stress for seven clay samples from Vajont.

\section{Discussion}

The mineralogical analyses of the clay layers involved in the 1963 Vajont landslide presented here revealed the presence of a large amount of clay minerals exclusively consisting of I/S mixed layers. This evidence is consistent with the analyses performed by [29], who proved for the first time the existence of I/S mixed layers in the clay mineral mixtures occurring within the rock mass involved in the slope rupture. Previous authors [21,27] recognized the simultaneous presence of montmorillonite and illite, even if in apparent discrete form. It must be pointed out that in the past, from a terminological point of view, authors often referred to "montmorillonite" to indicate undistinguished clay minerals belonging to the smectite group. According to these studies, the content of montmorillonite in the mineral mixture of the Vajont clays ranged between $25 \%$ and $75 \%$, whereas the overall content of clay minerals is $50-80 \%$. Our study revealed a slightly broader range in the clay mineral content of the analyzed samples (36-96\%). This difference can be justified by the larger number of samples investigated in the present work (nine) when compared to the number of samples analyzed by other authors (maximum three), thus reflecting a significant, previously undetected, variability in the mineralogical assemblages of the Vajont clays.

In fact, I/S mixed layer minerals are associated with highly variable amounts of calcite that ranges from low (4-10\%) to high percentages (64\%) (Table 2). The variable mixture of sheet minerals and calcareous fine-grained crystals produced different mineralogical assemblages that can be clearly recognized on examining the geochemical and mineralogical features of the analyzed clays (Figure 10). In the first group, clay minerals predominate (Group 1), whereas in the second group, calcite-rich sediments prevail (Group 2). Group 1 is characterized by lower values of $\mathrm{CaO}(5-22 \%)$ and LOI (14-25\%) (Figure 10a) and shows higher percentages of clay minerals (79-96\%) associated with considerable amounts of $\mathrm{K}_{2} \mathrm{O}(2.60-5.77 \%$, in most cases), which reflect an abundance of illite in the I/S mixed layers (Figure 10b). On the contrary, Group 2 shows lower percentages of interstratified I/S minerals (36-60\%), with the lowest values of $\mathrm{K}_{2} \mathrm{O}(1.17-2.30 \%)$ as well as the highest values of $\mathrm{CaO}$ (28-52\%) and LOI (25-33\%) (Figure 10). 
(a)

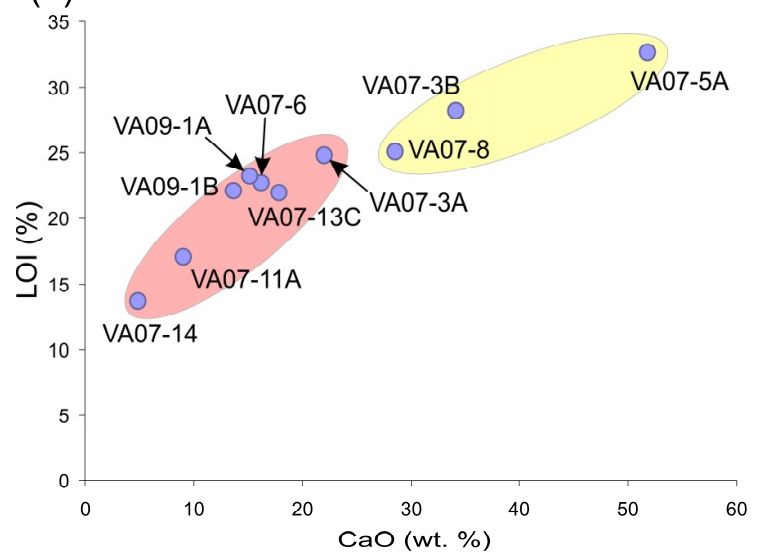

(b)

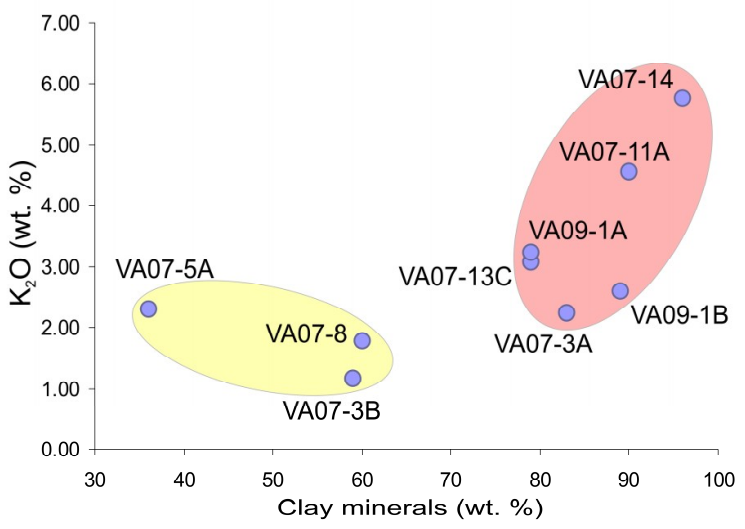

Figure 10. (a) LOI vs. CaO diagram of the clay samples from Vajont. (b) Diagram showing the relationship between the content of clay minerals from XRPD analyses and $\mathrm{K}_{2} \mathrm{O}$ content from XRF analyses of the Vajont clays. Two groups of different clay materials are highlighted.

The Atterberg limits of the clay materials determined in this work are consistent with other laboratory measurements carried out in the past by other authors $[21,27,28]$. The highest values of the liquid limit are in the range of $80-90 \%$, but greater values of LL were also reported, some samples reaching peak values of $106 \%[27,28]$. When considering shear strength properties, the weakest clay materials investigated in this study have characteristic values of the residual friction angle ranging from $\varphi_{\text {res }}=6.7^{\circ}$ to $\varphi_{\text {res }}=14.9^{\circ}$ (Table 3). These values of $\varphi_{\text {res }}$ are very much in line with previous laboratory determinations that are included in the range of $5-16^{\circ}$ [21,27-29]. Nonetheless, the residual shear tests carried out for this work also proved the existence of clay materials having greater values of the residual friction angle $\left(\varphi_{\text {res }}=19.5-26.7^{\circ}\right)$.

The ascertained great variability in the geotechnical index properties and shear resistance characteristics of the Vajont clays could tentatively be explained by comparing the geotechnical and mineralogical features of the clay interbeds. However, it must be pointed out that there is a strong difference, from both conceptual and practical points of view, between clay mineral content (CM) and clay fraction (CF). From a geotechnical point of view, clay fraction refers to fine-grained soils with a particle size lower than $2 \mu \mathrm{m}$, including clay minerals as well as other minerals of different nature and structure (e.g., calcite and quartz). This means that the percentages of minerals that have been determined for each sample through XRPD analyses (I/S mixed layers, calcite, and quartz) have to be reported to the corresponding clay fraction, thus $\mathrm{CF}$ and $\mathrm{CM}$ values cannot directly be correlated.

Most of the samples with a high content of clay minerals $(\mathrm{CM}>79 \%)$ are also characterized by higher plasticity properties (LL $>71 \%$, PI $>38 \%$; see Figure $8 \mathrm{a}$ ). In contrast, samples with a lower content of clay minerals ( $\mathrm{CM}<60 \%$ ) show lower plasticity properties ( $\mathrm{LL}<62 \%$, PI $<38 \%$ ). Nevertheless, two samples with a considerable content of clay minerals (CM $=83 \%$ for sample VA07-3A and $\mathrm{CM}=96 \%$ for sample VA07-14) have rather low plasticity properties (Figure 8a). Thus, the highest contents of clay minerals do not strictly correlate with the highest values of LL and PI. As a result, the amount of I/S mixed layers of the clay samples only marginally influences their plasticity properties.

Clay samples characterized by lower values of the residual friction angle (samples VA07-3A, VA07-6, VA07-11A, VA07-13C, and VA09-1A) exhibit highly variable values of CF (25-59\%), LL (52-89\%), and PI (30-59\%). According to the results of some torsional ring shear tests on cohesive soil samples [45], the increase in LL and CF results in a decrease in the drained residual shear strength. This correlation is nonlinear, especially for cohesive soils having CF greater than $50 \%$ and LL between $60 \%$ and $220 \%$. Most of the Vajont clays show an evident nonlinear decrease in the residual friction angle as the liquid limit increases (Figure 11a). Nevertheless, sample VA07-8, which is characterized by a higher residual friction angle, has values of CF, LL, and PI that are greater than corresponding values of other samples included in the group of low-strength clays (Table 3). The considerable variability in the residual 
friction angle of the Vajont clays is more evidently explained by their mineralogical composition, i.e., by the relative amount of the occurring clay minerals (Figure 11b). In fact, low-strength clays are dominated by high contents of clay minerals $(\mathrm{CM}>79 \%)$, whereas samples with higher values of the residual friction angle include a prevailing mixture of granular minerals (calcite and quartz).

(a)

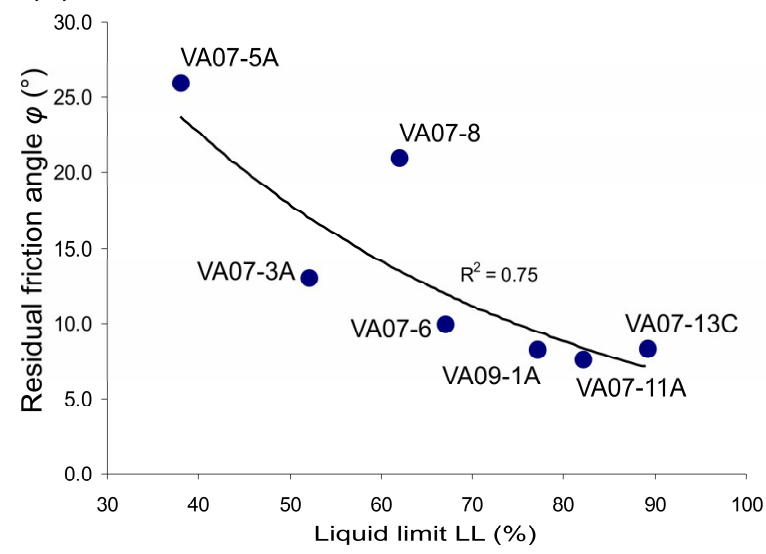

(b)

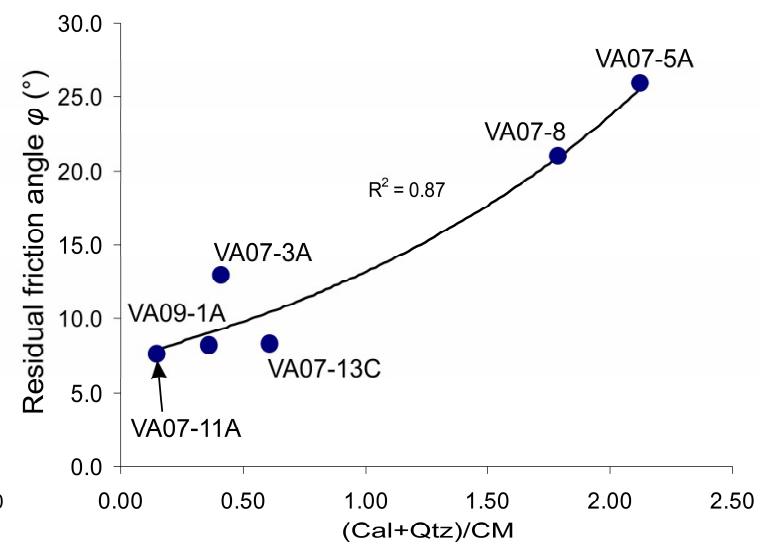

Figure 11. Correlation diagrams for some selected clay samples from Vajont, showing (a) residual friction angle vs. liquid limit and (b) residual friction angle vs. (calcite + quartz)/clay minerals ratio.

On the whole, the different mineralogical assemblages characterizing the Vajont clays and the relative amount of clay minerals seem to have a clear influence on the residual shear strength characteristics, but only partially affect their plasticity properties.

Field evidence ascertained that clay interbeds diffusely occur over the large detachment surface and within the remnants of the basal shear zone and that multiple thin clay layers concentrate in some specific rock strata sequences within the Fonzaso Fm., 1-2 m thick. This explains how the basal rupture surface of the slide did not form along a single, clay-rich level. On the contrary, the basal failure mechanism was driven by the presence of multiple and overlying clay layers, starting from the deepest interbeds of the Fonzaso Fm. occurring about 15-20 m above the lithostratigraphic contact with the underlying Calcare del Vajont Fm. As a result, the basal failure surface of the Vajont landslide has a complex stepped shape, involving several distinct clay-rich layers.

The characteristic stepped geometry of the basal failure surface of the slide demonstrates that the geotechnical models that consider a single, continuous, "critical" low-resistance clay layer at the base of the Vajont landslide e.g., $[21,25,26]$ are not consistent with field observations. This is true especially when considering the maximum thickness $(15-20 \mathrm{~cm})$ and the maximum ascertained continuity $(10-15 \mathrm{~m})$ of the clay lenses compared with the total extension of the failure surface that amounts to about $2 \mathrm{~km}^{2}$. On the contrary, the basal failure mechanism of the 1963 Vajont slide was complex and involved various geological materials, namely thin clay layers of variable shear strength, rock joints, cherty limestone beds, and angular gravel (Figure 3c). This means that the shear strength of the basal rupture zone cannot only be related to the residual shear resistance of the weakest materials, i.e., of the clays with a higher content of clay minerals; the shear strengths of the other materials involved in the basal rupture have also to be considered (Figure 12). The shear strength characteristics of these very heterogeneous materials are highly variable. Typical values of the friction angle for well-graded gravels and sandy gravels vary between $38^{\circ}$ and $46^{\circ}$ [46]. According to some triaxial shear tests on rockfill materials mainly consisting of angular to sub-angular particles, the friction angle varies between $41^{\circ}$ and $45^{\circ}$ [47]. In addition, values of the basic friction angle of flat unweathered limestone joints obtained through residual shear tests range between $27^{\circ}$ and $37^{\circ}$ [48]. 


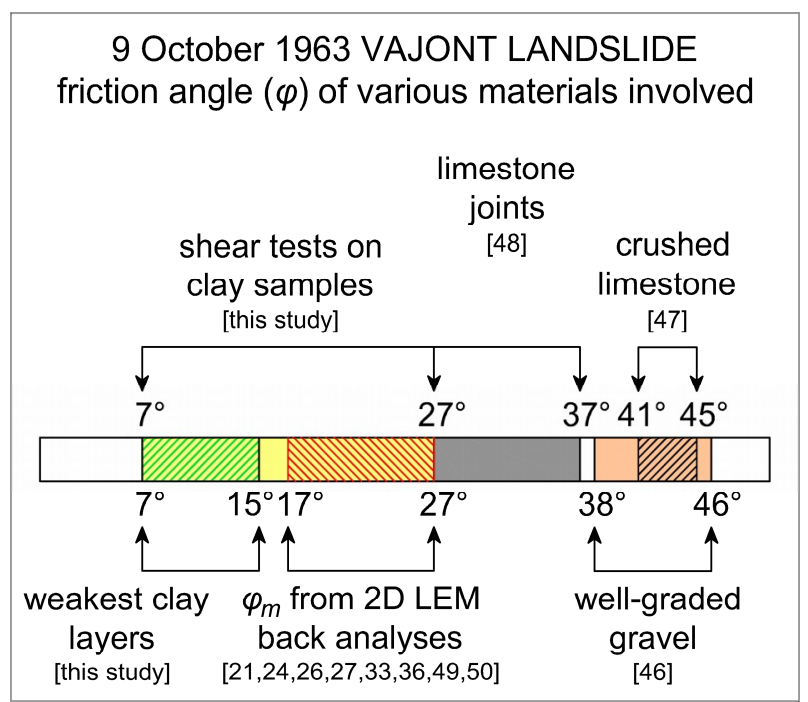

Figure 12. Typical ranges of the friction angle values of the different materials involved in the catastrophic collapse of the 1963 Vajont landslide.

When considering previous slope stability analyses of the 1963 Vajont landslide, typical two-dimensional back-calculated values of the friction angle $\varphi_{\mathrm{m}}$ range essentially from $17^{\circ}$ to $27^{\circ}[21,24,26,27,33,36,49,50]$. The latter are averaged values that simply reflect the notable heterogeneity of the strength properties of the different materials involved in the rupture. This finally explains the marked difference between the friction angles measured by means of different shear tests on various Vajont clay samples ( $\varphi=5-16^{\circ}$, prevailingly) and the typical back-calculated mean values at failure $\left(\varphi_{\mathrm{m}}=17-27^{\circ}\right)$ (Figure 12). Moreover, the particular dynamic features of the 1963 paroxysmal event and the remarkable velocity of the final collapse (about $20-30 \mathrm{~m} / \mathrm{s}$ ) cannot only be explained considering mechanical and/or thermal processes involving one or few clay layers located at the basal contact with the underlying bedrock.

\section{Conclusions}

The mineralogical investigations carried out for this study showed that the clay interbeds occurring within the Fonzaso Fm. and involved in the 1963 Vajont landslide are characterized by complex assemblages of illite/smectite (I/S) mixed layers admixed with variable amounts of calcite and quartz. The abundance of illite in the mixed-layer assemblages is confirmed by the high percentage of potassium as revealed by the geochemical analyses of the sampled clays. On the whole, the investigated clay samples are characterized by highly variable contents of clay minerals (36-96\%), calcite (4-64\%), and quartz (0-6\%).

The clay layers involved in the basal rupture of the 1963 slide show highly variable plasticity properties and shear strength characteristics. This evidence is explained by the close relationship between the mineralogical composition and shear strength properties of the Vajont clays. In fact, the samples with a large prevalence of clay minerals $(\mathrm{CM}>79 \%)$ are characterized by low values of $\varphi_{\text {res }}\left(6.7-14.9^{\circ}\right)$. These friction angle values are consistent with previous laboratory investigations conducted on Vajont clay samples to identify the weakest materials involved in the basal rupture ( $\varphi=5-16^{\circ}$, essentially). However, this study emphasizes the conclusion that other types of clay layers, with different mineralogical composition and geotechnical properties, were also involved in the formation of the basal rupture zone. These clay materials clearly show greater values of $\varphi_{\text {res }}\left(19.5-26.7^{\circ}\right)$ that are caused by a higher content of granular minerals (calcite and quartz). The coexistence of clay interbeds with highly variable shear resistance properties within the rock mass involved in the 1963 slope failure is pointed out for the first time by this study. 
The presence of the prehistoric shear zone interposed between the upper rock mass and the underlying bedrock had a strong influence on both the hydrogeological and mechanical behaviors of the slope. The high permeability of the limestone angular gravel $\left(k=5 \times 10^{-4} \mathrm{~m} / \mathrm{s} ;[24,36]\right)$ caused a rapid reservoir-induced inflow during the filling-drawdown operations performed in the years 1960-1963, thus originating a near-horizontal groundwater table that penetrated deeply into the slope (Figure 3a). The increase in the pore water pressure induced by the rising of the reservoir together with the low friction angle of the clay interbeds $\left(\varphi=7-27^{\circ}\right)$ were responsible for the overall shear strength reduction in correspondence with the basal rupture zone, thus favoring the huge sliding. However, most of the geotechnical models of the 1963 Vajont landslide assumed a single clay layer at the base of the unstable rock mass. This simplification does not correspond to reality. On the contrary, because of the presence of different materials in the basal shear zone of the Vajont landslide, the final rupture surface of the 1963 slide is related to the combined shear strength properties of discontinuous clay lenses, limestone stratification joints, angular gravel, and localized intact rock parts. This evidence should be kept in mind when assessing the geotechnical model of the 1963 slide and when performing slope stability back-analyses.

The 1963 Vajont landslide is a reference example of large rockslides involving clayey soils emplaced in sedimentary rock masses in correspondence with the basal rupture zone. The existence of low-strength materials at the base of large rockslides can result in an overall shear resistance decrease in correspondence with the rupture zone. However, the degree to which the strength decreases is mainly correlated to the strength properties of all the materials involved in the basal rupture, which may also include materials having different resistance properties than clays. To correctly evaluate the mechanical behavior and stability condition of large unstable rock slopes, a comprehensive understanding of the specific geological and geomechanical contexts is required. Very often, the geotechnical analysis of rockslides or unstable rock slopes is performed considering the mechanical properties of the involved geological materials (rocks and soils) in detail, but the same attention is rarely paid to the geological context, including the sedimentological, lithostratigraphical, and mineralogical features of the rock mass under investigation. This fact obviously depends on the various specializations involved in the specific research (geotechnical engineers, engineering geologists, geomorphologists, sedimentary geologists, mineralogists, etc.), but the consequence is a partial understanding of the studied phenomenon, if not even a misinterpretation of the geological factors leading to the slope rupture. The Vajont case history is an enlightening and very useful example to understanding the importance of the interdisciplinary studies connecting the typical geological-mineralogical approach with the geomechanical investigation of unstable rock slopes.

Author Contributions: Conceptualization, A.B.; methodology, A.B., P.P., D.P., D.L., and M.D.F.; validation, A.B.; formal analysis, A.B., P.P., D.P., D.L., and M.D.F.; investigation, A.B., P.P., D.P., D.L., and M.D.F.; resources, A.B., P.P., D.P., D.L., and M.D.F.; data curation, A.B.; writing—original draft preparation, A.B.; writing-review and editing, A.B., P.P., D.P., D.L., and M.D.F.; visualization, A.B.; supervision, A.B.; project administration, A.B. All authors have read and agreed to the published version of the manuscript.

Funding: This research received no external funding.

Conflicts of Interest: The authors declare no conflict of interest.

\section{References}

1. Paronuzzi, P.; Bolla, A. Gravity-induced rock mass damage related to large en masse rockslides: Evidence from Vajont. Geomorphology 2015, 234, 28-53. [CrossRef]

2. Shuzui, H. Process of slip-surface development and formation of slip-surface clay in landslides in Tertiary volcanic rocks, Japan. Eng. Geol. 2001, 61, 199-219. [CrossRef]

3. Wang, W.-N.; Chigira, M.; Furuya, T. Geological and geomorphological precursors of the Chiu-fen-erh-shan landslide triggered by the Chi-chi earthquake in central Taiwan. Eng. Geol. 2003, 69, 1-13. [CrossRef]

4. Braathen, A.; Blikra, L.H.; Berg, S.S.; Karlsen, F. Rock-slope failures in Norway; type, geometry and hazard. Nor. J. Geol. 2004, 84, 67-88. 
5. Grøneng, G.; Nilsen, B.; Sandven, R. Shear strength estimation for Åknes sliding area in western Norway. Int. J. Rock Mech. Min. Sci. 2009, 46, 479-488. [CrossRef]

6. Tommasi, P.; Verrucci, L.; Campedel, P.; Veronese, L.; Pettinelli, E.; Ribacchi, R. Buckling of high naturalslopes: The case of Lavini di Marco (Trento-Italy). Eng. Geol. 2009, 109, 93-108. [CrossRef]

7. Strauhal, T.; Zangerl, C.; Fellin, W.; Holzmann, M.; Engl, D.A.; Brandner, R.; Tropper, P.; Tessadri, R. Structure, Mineralogy and Geomechanical Properties of Shear Zones of Deep-Seated Rockslides in Metamorphic Rocks (Tyrol, Austria). Rock Mech. Rock Eng. 2017, 50, 419-438. [CrossRef]

8. Ganerød, G.V.; Grøneng, G.; Rønning, J.S.; Dalsegg, E.; Elvebakk, H.; Tønnesen, J.F.; Kveldsvik, V.; Eiken, T.; Blikra, L.H.; Braathen, A. Geological model of the Åknes rockslide, western Norway. Eng. Geol. 2008, 102, 1-18. [CrossRef]

9. Wang, F.; Zhang, Y.; Huo, Z.; Peng, X.; Wang, S.; Yamasaki, S. Mechanism for rapid motion of the Qianjiangping landslide during reactivation by the first impoundment of the Three Gorges Dam reservoir, China. Landslides 2008, 5, 379-386. [CrossRef]

10. Tsou, C.-Y.; Feng, Z.-Y.; Chigira, M. Catastrophic landslide induced by Typhoon Morakot, Shiaolin, Taiwan. Geomorphology 2011, 127, 166-178. [CrossRef]

11. Chigira, M.; Hariyama, T.; Yamasaki, S. Development of deep-seated gravitational slope deformation on shale dip-slope: Observations from high-quality drill cores. Tectonophysics 2013, 605, 104-113. [CrossRef]

12. Furuki, H.; Chigira, M. Structural features and evolutionary mechanisms of the basal shear zone of a rockslide. Eng. Geol. 2019, 260, 105214. [CrossRef]

13. Chigira, M.; Wang, W.-N.; Furuya, T.; Kamai, T. Geological causes and geomorphological precursors of the Tsaoling landslide triggered by the 1999 Chi-Chi earthquake, Taiwan. Eng. Geol. 2003, 68, 259-273. [CrossRef]

14. Eberhardt, E.; Thuro, K.; Luginbuehl, M. Slope instability mechanisms in dipping interbedded conglomerates and weathered marls-The 1999 Rufi landslide, Switzerland. Eng. Geol. 2005, 77, 35-56. [CrossRef]

15. Bonzanigo, L.; Eberhardt, E.; Loew, S. Long-term investigation of a deep-seated creeping landslide in crystalline rock. Part I. Geological and hydromechanical factors controlling the Campo Vallemaggia landslide. Can. Geotec. J. 2007, 44, 1157-1180. [CrossRef]

16. Azañón, J.M.; Azor, A.; Yesares, J.; Tsige, M.; Mateos, R.M.; Nieto, F.; Delgado, J.; López-Chicano, M.; Martín, W.; Rodríguez-Fernández, J. Regional-scale high-plasticity clay-bearing formation as controlling factor on landslides in Southeast Spain. Geomorphology 2010, 120, 26-37. [CrossRef]

17. Regmi, A.D.; Yoshida, K.; Cui, P.; Hatano, N. Development of Taprang landslide, West Nepal. Landslides 2017, 14, 929-946. [CrossRef]

18. Esposito, C.; Bianchi-Fasani, G.; Martino, S.; Scarascia-Mugnozza, G. Quaternary gravitational morpho-genesis of Central Apennines (Italy): Insights from the Mt. Genzana case history. Tectonophysics 2013, 605, 96-103. [CrossRef]

19. Massey, C.I.; Petley, D.N.; McSaveney, M.J. Patterns of movement in reactivated landslides. Eng. Geol. 2013, 159, 1-19. [CrossRef]

20. Tonelli, G.; Veneri, F.; Mattioli, M.; Paletta, C. The role of a bentonitic layer on slope stability in bedded limestone: The case study of the December $2004 \mathrm{Ca}^{\prime}$ Madonna Quarry rock slide (Umbria-Marche Apennines, Central Italy). Ital. J. Geosci. 2019, 138, 56-65.

21. Hendron, A.J.; Patton, F.D. The Vaiont Slide, a Geotechnical Analysis Based on New Geologic Observations of the Failure Surface; Technical Report GL-85-5; Department of the Army, U.S. Army Corps of Engineers: Washington, DC, USA, 1985; p. 324.

22. Paronuzzi, P.; Bolla, A. The prehistoric Vajont rockslide: An updated geological model. Geomorphology 2012, 169-170, 165-191. [CrossRef]

23. Paronuzzi, P.; Bolla, A. A new interpretation of the geotechnical context of the Vajont rockslide. In Landslide Science and Practice: Risk Assessment, Management and Mitigation; Margottini, C., Canuti, P., Sassa, K., Eds.; Springer: Berlin/Heidelberg, Germany, 2013; pp. 123-132.

24. Paronuzzi, P.; Rigo, E.; Bolla, A. Influence of filling-drawdown cycles of the Vajont reservoir on Mt. Toc slope stability. Geomorphology 2013, 191, 75-93. [CrossRef]

25. Boon, C.W.; Houlsby, G.T.; Utili, S. New insights into the 1963 Vajont slide using 2D and 3D distinct-element method analyses. Géotechnique 2014, 64, 800-816. [CrossRef] 
26. Dykes, A.P.; Bromhead, E.N. New, simplified and improved interpretation of the Vaiont landslide mechanics. Landslides 2018, 15, 2001-2015. [CrossRef]

27. Kenney, T.C. The influence of mineral composition on the residual strength of natural soils. In Proceedings of the Geotechnical Conference; Norwegian Geotechnical Institute: Oslo, Norway, 1967; pp. 123-129.

28. Nonveiller, E. Shear strength of bedded and jointed rock as determined from the Zalesina and Vajont slides. In Proceedings of the Geotechnical Conference; Norwegian Geotechnical Institute: Oslo, Norway, 1967; pp. 289-294.

29. Tika, T.E.; Hutchinson, J.N. Ring shear tests on soil from the Vaiont slide slip surface. Géotechnique 1999, 49, 59-74. [CrossRef]

30. Terzaghi, R.; Voight, B. Karl Terzaghi on rockslides: The perspective of a half-century. In Rockslides and Avalanches; Voight, B., Ed.; Elsevier: New York, NY, USA, 1979; Part 2; pp. 111-131.

31. Hoek, E. Practical Rock Engineering. Available online: http://www.rocscience.com/educational/hoeks_corner (accessed on 15 August 2020).

32. Nonveiller, E. Discussion of paper by V. Mencl on mechanics of landslides with noncircular surfaces with special reference to Vaiont slide. Géotechnique 1967, 17, 170-171. [CrossRef]

33. Müller, L. New considerations on the Vaiont slide. Rock Mech. Eng. Geol. 1968, 6, 1-91.

34. Kenney, T.C. Slope stability in artificial reservoirs: Influence of reservoir level, selected cases, and possible solutions. In Proceedings of the Meeting on the 1963 Vaiont Landslide, Ferrara, Cansiglio and Vaiont, 17-19 September 1986; Semenza, E., Melidoro, G., Eds.; Grafica Ferrarese: Ferrara, Italy, 1992; pp. 67-85.

35. Petley, D.N.; Petley, D.J. On initiation of large rockslides: Perspectives from a new analysis of the Vaiont movement record. In Landslides from Massive Rock Slope Failure; Evans, S.G., Scarascia Mugnozza, G., Strom, A., Hermanns, R.L., Eds.; Springer: Dordrecht, The Netherlands, 2006; pp. 77-84.

36. Paronuzzi, P.; Rigo, E.; Bolla, A. A coupled seepage-stability model to analyze the Vajont reservoir influence. In Landslide Science and Practice: Risk Assessment, Management and Mitigation; Margottini, C., Canuti, P., Sassa, K., Eds.; Springer: Berlin/Heidelberg, Germany, 2013; pp. 97-106.

37. Paronuzzi, P.; Bolla, A.; Rigo, E. Brittle and ductile behavior in deep-seated landslides: Learning from the Vajont experience. Rock Mech. Rock Eng. 2016, 49, 2389-2411. [CrossRef]

38. Wolter, A.; Stead, D.; Ward, B.C.; Clague, J.J.; Ghirotti, M. Engineering geomorphological characterisation of the Vajont Slide, Italy, and a new interpretation of the chronology and evolution of the landslide. Landslides 2016, 13, 1067-1081. [CrossRef]

39. Dykes, A.P.; Bromhead, E.N. The Vaiont landslide: Re-assessment of the evidence leads to rejection of the consensus. Landslides 2018, 15, 1815-1832. [CrossRef]

40. Paronuzzi, P.; Bolla, A. Gravity-induced fracturing in large rockslides: Possible evidence from Vajont. In Engineering Geology for Society and Territory: Landslide Processes, Proceedings of the XII International IAEG Congress, Turin, Italy, 15-19 September 2014; Lollino, G., Giordan, D., Crosta, G.B., Corominas, J., Azzam, R., Wasowski, J., Sciarra, N., Eds.; Springer: Berlin/Heidelberg, Germany, 2015; pp. 213-216.

41. Moore, D.M.; Reynolds, R.C., Jr. X-ray Diffraction and the Identification and Analysis of Clay Minerals, 2nd ed.; Oxford University Press: New York, NY, USA, 1997; p. 332.

42. Laviano, R. Analisi mineralogica quantitativa di argille mediante diffrattometria di raggi X. In Proceedings of the Conference on: Procedure di Analisi di Materiali Argillosi, 1-2 June 1987, Lerici, Italy; ENEA: Rome, Italy, 1987; pp. 215-234.

43. Casagrande, A. Classification and identification of soils. Trans. ASCE 1948, 113, 901-991.

44. American Society for Testing and Materials. Standard Classification of Soils for Engineering Purposes, Test Designation D 2487. 1993, Volume 04.08. Available online: https://www.astm.org/Standards/D2487 (accessed on 6 September 2020).

45. Stark, T.D.; Eid, H.T. Drained residual strength of cohesive soils. J. Geotech. Eng. 1994, 120, 856-871. [CrossRef]

46. Schmertmann, J.H. Guidelines for Cone Penetration Test. Performance and Design; TS-78-209; U.S. Department of Transportation, Federal Highway Administration: Washington, DC, USA, 1978.

47. Sharma, P.; Mahure, N.V.; Ratnam, M. Influence of different stress conditions on behavior of rockfill materials. Geotech. Geol. Eng. 2011, 29, 1035-1048. [CrossRef] 
48. Coulson, J.H. Shear strength of flat surfaces in rock. In Proceedings of the 13th Symposium on Rock Mechanics, Urbana, IL, USA; Cording, E.J., Ed.; American Society of Civil Engineers: New York, NY, USA, 1972; pp. 77-105.

49. Nonveiller, E. The stability analysis of slopes with a slip surface of general shape. In Proceedings of the 6 th International Conference on Soil Mechanics and Foundation Engineering, Montreal, QC, Canada; University of Toronto Press: Toronto, Canada, 1965; Volume 2, Div. 6.

50. Mencl, V. Mechanics of landslides with noncircular slip surfaces with special reference to Vaiont slide. Géotechnique 1966, 16, 329-337. [CrossRef]

(C) 2020 by the authors. Licensee MDPI, Basel, Switzerland. This article is an open access article distributed under the terms and conditions of the Creative Commons Attribution (CC BY) license (http://creativecommons.org/licenses/by/4.0/). 